\title{
The Role of Competencies and Education in Increasing Entrepreneurial Intention in Creative Economy
}

\author{
Christine Winstinindah Sandroto, Yussi Ramawati, Syarief Darmoyo \\ Atma Jaya Catholic University of Indonesia, Jl. Jenderal Sudirman 51, Jakarta 12930
}

A R T I C L E I N F O
Keywords:
entrepreneurial competencies,
education level,
creative economy,
entrepreneurial intention

Kata Kunci:

kompetensi wirausaha, tingkat pendidikan,

ekonomi kreatif,

intensi wirausaha

\section{A B S T R A C T}

The creative economy is being increasingly encouraged by the Indonesian government, the existing entrepreneurs are mostly engaged in the culinary industry. This study aims to describe the role of competencies and education in increasing entrepreneurial intention in the creative economy. Three hundred and five questionnaires were distributed to creative entrepreneurs, consisting of 162 respondents in Jakarta and 143 in Balikpapan using convenience sampling. Research findings show that there is no difference between the mean scores of entrepreneurial competencies in Jakarta and Balikpapan. Furthermore, the level of education has a positive effect on (i) entrepreneurial intention, (ii) entrepreneurial professional attraction, and (iii) entrepreneurial networking support. There is a positive relationship between education level and monthly revenue, as well as between entrepreneurial competencies and monthly revenue. The findings of this research would suggest government and education institution to further develop entrepreneurship education and train them with various methods and to cultivate interests in other creative sub-sectors.

SARI PATI

Ekonomi kreatif saat ini semakin digalakkan oleh pemerintah, namun kenyataannya hanya bidang kuliner yang diminati oleh pelaku usaha. Penelitian ini bertujuan untuk menggambarkan peran competencies dan pendidikan untuk meningkatkan ketertarikan berwirausaha di bidang kreatif ekonomi. Populasi dalam penelitian ini adalah para pelakuusaha pada kreatif ekonomidiJakarta danBalikpapan. Penelitian ini menyebarkan kuesioner kepada 305 responden yang terdiri dari 162 responden di wilayah Jakarta dan 143 di Balikpapan, dengan teknik convenience sampling. Hasil penelitian menunjukkan bahwa tidak ada perbedaan nilai rata-rata entrepreneurial competencies antara Jakarta dan Balikpapan. Lebih lanjut tingkat pendidikan berpengaruh positif terhadap (i) entrepreneurial intention, (ii) professional attraction entrepreneurial, dan (iii) networking support entrepreneurial. Terdapat 
hubungan yang positif antara tingkat pendidikan dan pendapatan/ bulan, serta terdapat hubungan yang positif antara entrepreneurial competencies dan pendapatan/bulan. Saran dalam penelitian ini agar lebih mengembangkan pendidikan kewirausahaan dan mempertajam dengan berbagai metoda. Mengedukasi dan melatih agar tertarik pada bidang industri kreatif lainnya selain kuliner.

(C) 2018 IRJBS, All rights reserved.

\section{INTRODUCTION}

Indonesia is one of the world's most economicallyperforming countries. In 2015, the country recorded 4.79\% Gross Domestic Product (GDP) growth, higher than the $2.4 \%$ global economic growth. This positive climate provides the Indonesian government with an opportunity to strengthen the foundations of the economy, specifically in the real sector. One of the sectors that deserve to be prioritized is the creative economy, Creative economy can also be called as creative industry or cultural industry. The creative economy has an advantage over some sectors, i.e. an economy that is centered on the skills of the human resources; unlike those that heavily rely on the exploitation of natural resources. For example, art, architecture, book, technological innovation, and animation are all results of derived ideas. The creative economy industry is the hope for Indonesia amid the global economic turmoil (Bekraf, 2017).

In 2014 - 2015 the value-added of the creative economy sector was estimated to be 111.1 trillion Rupiah, with fashion, culinary, and handicraft subsectors as the largest contributors to this number (Kemenperin, 2015). This surely improves the competitiveness of products and businesses in Indonesia. As a result, there are many start-up businesses that are emerging in the country. The government also expresses its support of the creative economy by issuing Presidential Regulation No. 6 of 2015 on Creative Economy Board which was amended by Presidential Regulation No. 72 of 2015. There are sixteen creative economic subsectors mentioned in the regulation. The overall potential of the nation's creative economy needs to be continuously developed by mapping out the creative economic potentials in every province in Indonesia.

The creative economy contributed 7.13 percent to the GDP during 2010-2014. In 2010, the GDP contribution was recorded at Rp473 trillion, while in 2013 the number increased to Rp641 trillion. The highest growth of creative economies can be traced to Jakarta, Bandung, Yogyakarta, and Bali (Enciety News, 2015). Conversely, in Kalimantan, the growth of creative industries remains not only low but also due to the underdevelopment of most of the sub-sectors. Kalimantan is, however, superior when it comes to food and craft (Pro Kaltim, 2016).

The creative economy employes creativity, skill, aptitude, and individual competence. The creative economy is able to support long-term government programs, therefore it is appropriate if the level of competitiveness is also complemented by the competence of the human resources and entrepreneurial intention in the creative economy.

Aside from working as an employee, people can choose to be an entrepreneur. Some people perceive that being an entrepreneur is a valuable opportunity (opportunity entrepreneurship). Others become entrepreneur due to unemployment (necessity entrepreneurship). Necessity entrepreneurs are generally not highly educated. It is not surprising that previous articles suggest that necessity entrepreneurs possess 
the lower likelihood to success compared to opportunity entrepreneurs (J. H. Block \& Wagner, 2010; J. Block \& Sandner, 2009; Verheul et al., 2010). Nevertheless, these necessity entrepreneurs may end up successful if they receive adequate training and education to improve their competence, along with government support that includes the introduction of policies that promote creative economy.

Based on the given introduction, this research would examine the competence of creative entrepreneurs, identify the creative industries that are of interest, and assess how the level of education influences entrepreneurial intention and new venture creation.

\section{LITERATURE REVIEW}

\section{Creative Economy}

According to Tian \& Gao (2011), a creative economy is a form of advanced economic development that relies on fewer natural resources. Its main driver is not purely technology or information, but human creativity, creative and unique products that combine culture, spirit, and habit. The creative industry is a human-oriented industry. Protection of intellectual property serves to preserve the vital energy of the creative industry. Companies gain benefit from symbiotic mutualisms and access to high industry value chains. According to Wang \& Peng (2009), creative industry is different from the consumer goods industry, where production depends on machines or labor. The creative industry generates output from intellectual capital, marked with originality.

The Creative Economy Board (or known in Indonesia as Bekraf) is a non-ministerial government institution responsible for the sixteen sub-sectors of the creative economy: 1 . Application and Game Development; 2. Architecture; 3. Interior design; 4. Visual communication design; 5. Design Products; 6. Fashion; 7. The Movie, Animation, and Video; 8. Photography; 9. Craft; 10. Culinary; 11. Music; 12. Publishing; 13. Advertising;
14. Performing Arts; 15. Art; and 16. Television and Radio. Indonesia expects every province to develop several creative sub-sectors in order to increase the economic growth in their respective regions.

\section{Entrepreneurship}

Entrepreneurship is defined as «the occupational choice to work for one's account and risk» (Stephan and Uhlaner, 2010). An entrepreneur is somebody who creates a new business in the face of risk and uncertainty for the purpose of achieving profit and growth by identifying significant opportunities and assembling the necessary resources to capitalize on them (Scarboroug and Cornwall, 2016). Starting part-time business is a popular gateway to entrepreneurship. Part-time entrepreneurs have the best of both worlds: they can ease into business for themselves without sacrificing the security of a steady paycheck and benefits. The Internet (and particularly e-bay) and mobile communication devices make establishing and running a part-time business very easy; many parttime entrepreneurs run online businesses from a spare bedroom in their homes or from wherever they are (Scarboroug and Cornwall, 2016).

According to Reynolds et al., (2001), there are two types of entrepreneurs: necessity entrepreneurs and opportunity entrepreneurs. The difference between these two types of entrepreneurs lies in their underlying motives for starting a business. Necessity entrepreneurs are those who are driven into the entrepreneurial world as needbased (Block and Wagner, 2010). They become entrepreneurs by default because they do not have an alternative (Verheul et al., 2010), i.e. a non-voluntary decision (Reynolds et al., 2001). Moreover, this kind of constraint usually does not satisfy one's self. (Bhola et al., 2006).

Opportunity entrepreneurs are those who establish a business to pursue an opportunity (Block and Wagner, 2010). They mobilize efforts to take advantage of business opportunities 
based on personal interests (Verheul et al., 2010); thus, enabling them to enter the entrepreneurial world by choice. Oftentimes, entrepreneurs who are driven by necessity are more to experience failure compared to opportunity (Bhola et al., 2006; Block and Wagner, 2010; Block and Sandner, 2009; Verheul et al., 2010). Additionally, necessity entrepreneurs do not normally have the formidable educational background. However, these entrepreneurs might achieve success if they receive adequate training and education to improve their competence, along with government support that includes the introduction of policies that promote creative economy.

\section{Entrepreneurial Competency}

Competency is defined as an underlying characteristic of an individual that is causally related to criterion-referenced effective and/or superior performance in a job or situation. There are five characteristics of competence: motives, traits, self-concept, knowledge, and skills (Spencer and Spencer, 1993). Knowledge and skills are usually associated with hard skill competencies, while personality is usually associated with soft skill competencies (Shermon, 2004).

Spencer and Spencer (1993) state that entrepreneurial competencies include both hard and soft skills: (i) achievement, (ii) thinking and problem-solving, (iii) personal maturity, (iv) influence, (v) directing and controlling, (vi) orientation to others, and (vii) additional competencies. Based on the duties and scope of responsibilities, experts develop entrepreneurial competence. Entrepreneurial hard skill competencies, according to Chou, Shen, and Chen, and Hsiao (as referenced in Riyanti, Sandroto, and Warmiyati, 2016), consisting of ten competencies among business students: (i). entrepreneurial spirit and entrepreneurial competencies, (ii) marketing competence, (iii) business and economics competence, (iv) financial competence, (v) accounting affair competence, (vi) management competence, (vii) globalization competence, (viii) business law competence, (ix) enterprise resource planning competence, and ( $\mathrm{x}$ ) information technology competence.

\section{Entrepreneurial Intention}

Soutaris et al. (2007) (as referenced in Mohammad et al., 2015) define entrepreneurial intention as one's desire to begin an entrepreneurial activity. Shapero \& Sokol (1982) argue that intention of becoming an entrepreneur depends on the following three dimensions: perceived desirability, perceived feasibility, and propensity to act. Shapero \& Sokol (1982) adapted the Planned Behavior theory that was proposed by Fishbein \& Ajzen (1975) and specifically applied it to the field of entrepreneurship.

Ajzen (1991) furtherly developed the theory of Planned Behavior. This theory comprises several variables: (i) background factors; (ii) behavioral belief; (iii) normative beliefs; (iv) subjective norm; (v) control beliefs; and (vi) perceived behavioral control perception. According to the theory of Planned Behavior, a person can be determined to act in a certain way only if he or she has control over his or her behavior. This theory not only emphasizes the rationality of human behavior but also the belief that the target behavior is under the control of the individual's consciousness; or a behavior depends not only on the intentions of the individual but also on other factors that are not under the control of the individual such as the availability of resources and opportunities to perform such behavior. Theory of Planned Behavior dictates the intention is a function of three determinants, they are: being personal, reflecting social influences and relating to control problems (Ajzen and Fishbein, 2005).

\section{Education Level and Entrepreneurial intention}

Previous studies have found that the creation of new ventures had been planned (Bird, 1988; Autio et al., 1997; Tkachev and Kolvereid, 1999 in Mushtaq et al., 2011 and Shapero and Sokol, 1982). The difficult and challenging nature 
of entrepreneurship causes many freshlyestablished businesses to fail. Entrepreneurship requires enhanced management capabilities to grow businesses and fight off competitions. Several studies have given the evidence of the importance of university education to anticipate and clarify individual behaviors related to new venture creation (Kolvlereid, 1996; Krueger 1993 in Mushtaq et al., 2011). Entrepreneurship education and training have an immediate impact on students and their behavioral intention (Kolvereid and Moen, 1997). This indicates that there is a difference between those who take entrepreneurial and non-entrepreneurial education. Education, therefore, plays an important role in improving entrepreneurship and number or entrepreneurs. In new venture creations, entrepreneurs usually rely on network support, social norms, the perception of feasibility, and entrepreneurial experience. After possessing the aforementioned entrepreneurial skills and abilities, the attitude of the graduate change; they are more interested in entrepreneurship. The rise in interest is triggered by the learning process, considering that education provides the information needed (Cooper, 1985).

The transformation of thought to become an entrepreneur is well thought out and deliberate, and this is influenced by education (Krueger, Reilly, and Carsrud, 2000). As a result of the adjustments and improvements in the formal education system and the vocational and other professional training programmes, some important objectives could be achieved, they are: (1) a better transferability of the different programmes-through the credit system; (2) a more transparent system of qualificationthrough the professional qualification of training programmes and training organisations; and (3) a better understanding of entrepreneurship not only by entrepreneurs, but within a wider section of society including local and regional authorities, development agencies, financing institutions and the organisations of the civil sector (Konczol, 2004). The rising demand for entrepreneurship learning reveals the requirement to depart university prepared with the understanding and expertise essential to carry on in modern day's competitive set. After gaining the required entrepreneurial skills and abilities, the attitude has changed and they were more attracted toward entrepreneurship. The importance of know-how and learning has broadly drawn attention, specifically to the enhanced information the education is providing (Mushtaq et al, 2011)

Studies about the role of the entrepreneurial network reveal that the network is related to businesses being started (Gartner \& Carter, 2003). Prior studies have found that past entrepreneurial experience tends to expand a set of heterogeneous social networks that are beneficial for the development of start-up businesses (Mosey \& Wright, 2007). Networking behavior is defined as individuals' attempt to develop and maintain relationships with others who have the potential to assist them in their work or career. Networking is a type of proactive behavior. It is also noted as an important source of sales prospect (Macintosh \& Krush, 2017).

Self-reliance is needed in relation to the level of creativity and modernity of a person in choosing the latest methods and knowledge to apply to local conditions (Acho-Chi, 1998). Self-reliance is defined as a mindset that observes individual minds and physical resources, as the basic reserve to describe on the search of one's aims and goals and discovers sentimental accomplishment not only in attaining the objectives but encompassing them by means of personal resources (Rahman, 1993).

Based on the phenomena that have been mentioned, this study would assess entrepreneurial competencies, the respondents' preferred sub-sectors of the creative economy, and how educational attainment influence entrepreneurial intention and new venture creation (professional attraction, networking support, and self-reliance). The findings of the study are expected to determine 
the development of entrepreneurial spirit in the nation's creative economy.

\section{Research Question}

To measure entrepreneurial competencies and to measure how the effect of educational level toward entrepreneurial intention, professional attraction, networking support, and self-reliance in creative economy in Jakarta and Balikpapan.

\section{METHODS}

This descriptive study employs the causalcomparative technique. Questionnaires were distributed to the respondents to measure five variables: entrepreneurial intention, professional attraction, networking support, self-reliance, and level of education.

\section{Conceptual Hypothesis}

1. There is a difference in achievement competency between Jakarta and Balikpapan.

2. There is a difference in thinking and problemsolving competency between Jakarta andBalikpapan.

3. There is a difference in personal maturity competency between Jakarta and Balikpapan.

4. There is a difference in influence competency between Jakarta and Balikpapan.

5. There is a difference in directing and controlling competency between Jakarta and Balikpapan.

6. There is a difference in orientation to others competency between Jakarta and Balikpapan.

7. There is a difference in entrepreneur competencies between Jakarta and Balikpapan.

8. There is an effect of level of education on entrepreneurial intention.

9. There is an effect of level of education on professional attraction.

10. There is an effect of level of education on networking support.

11. There is an effect of level of education on selfreliance.

12. There is a correlation between education level and monthly revenue.
13. There is a correlation between entrepreneurship competencies and monthly revenue.

\section{Population and Sampling}

The population of this research included all creative entrepreneurs, both full time and part time in Jakarta and Balikpapan. These cities were chosen due to the similarities on potential and existing differences on industry management. Convenience sampling was performed: questionnaires were distributed to 305 entrepreneurs-162 in Jakarta and 143 in Balikpapan. The sampling method used in this study is non-probability sampling, ie not all subjects have equal opportunity to be a research sample (Kerlinger \& Lee, 2000).

\section{Data and Measurement}

In measuring the research variables, this study adapted the scales that had been formerly developed. Entrepreneurial competencies (EC) were measured using Spencer and Spencer scale (1993) containing 23 items of questions for achievement dimensions ( $\mathrm{ACH}), 6$ questions for thinking and problem-solving dimensions (TPS), 13 questions for personal maturity (PM) dimensions, 11 questions for influence dimension (INF), 6 questions for directing and controlling dimension (DC), and 14 questions for orientation to others (OTO) dimension.

Respondents were asked to indicate their level of approval of question items on a 7-point Likert scale, ranging from strong disagreement (1) to strong agreement (7). Validity and reliability test results show the scale to be valid and reliable (correlation coefficient EC ranged from 0.595 - 0.872; p < $<.01$, $\mathrm{ACH}$ ranged from $0.696-0.837 ; \mathrm{p}<0.01$, TPS ranged from $0.859-0.913 ; \mathrm{p}<0.01$, PM ranged from 0.675 - 0.848; p <0.01, INF ranged from $0.768-0.858$; $\mathrm{p}$ $<0.01$, DC rangesd from $0.796-0.898$; $<<0.01$ OTO ranged from $0.844-0.931 ; \mathrm{p}<0.01$ Cronbach 'alpha coefficient $\mathrm{EC}=0.990$, Cronbach 'alpha coefficient $\mathrm{ACH}=0.970$, Cronbach' alpha coefficient TPS $=$ 0.945, Cronbach 'alpha coefficient PM $=0.951$, Cronbach' alpha coefficient INF $=0.951$, Cronbach 
'alpha coefficient DC $=0.915$, and Cronbach' alpha coefficient OTO = 0.979).

Entrepreneurial Intention (EI) was measured through a scale developed by Alhaj, Yusof, and Edama (2011). This scale consisted of 7 question items. Respondents were asked to indicate their level of approval of the item questions on a 7-point Likert scale, ranging from strong disagreement (1) to strong agreement (7). The validity and reliability test results show that this scale was valid and reliable (correlation coefficient EI ranged from 0.825 - 0.941 and significant at 0.01 ; Cronbach' alpha coefficient $\mathrm{EI}=0.806$ )

Professional attraction (PA), Networking support (NS), and Self-reliance (SR) were measured using the scale developed by Mushtaq et al., (2011). The scale consisted of 3 questions each for PA and NS, and 4 questions for SR. Respondents were asked to indicate their level of approval of the item questions on a 7-point Likert scale, ranging from strong disagreement (1) to strong agreement (7) The validity and reliability test results show that the three scales were valid and reliable (correlation coefficient PA ranged from $0.887-0.940$ and significant at $\mathrm{p}=0.01$, the NS ranges from 0.943 0.958 and is significant at 0.01 , and the SR ranged from 0.837 - 0.897 and significant at 0.01 ; Cronbach 'alpha coefficient PA $=0.931$, Cronbach' alpha coefficient NS $=0.946$, and Cronbach 'alpha coefficient $\mathrm{SR}=0.882$ ).

Education level is defined as (i) the last formal education diploma received by the respondent, and (ii) the duration of formal education pursuit in terms of years.

\section{Data Analysis}

Data were analyzed descriptively and inductively. Descriptive statistics were used to describe the research variables and the demography of the respondents, as well as the perceptions of entrepreneurial competencies with crosstabs and mean score. Inductive statistics were performed to test the hypotheses using linear regression and independent samples t-test, and Spearman's rank correlation.

\section{Description of Respondents}

Three hundred and five entrepreneurs participated in this research: 162 respondents in Jakarta and 143 in Balikpapan. Some questionnaires were returned incompletely, i.e. some questions left unanswered; this caused inequality in the number of respondents for some questions. Outliers were also eliminated prior to analysis.

\section{Descriptive Statistics}

The characteristics of the respondents are presented in Table 1.

In Jakarta, the majority of the respondents are in the 16-to-26 age range and male. In Balikpapan, the majority of the entrepreneurs are middle-aged (38-48 years of age) and female. In Jakarta and Balikpapan, majority respondents are married. In terms of experience, most of the respondents have only been working as entrepreneurs for less than six years. Both in Jakarta and Balikpapan, the highest percentage for education is senior high school and followed by an undergraduate degree, while the rest are spread out among primary school, junior high school, and diploma. Both cities show that most respondents are fulltime entrepreneurs. They are all mostly full-time entrepreneurs. Finally, when it comes to monthly revenue, there are those who earn more than 500 million Rupiah in Jakarta, but most entrepreneurs in both cities earn less than 10 million Rupiah every month.

Overall entrepreneurial competencies in both Jakarta and Balikpapan are high, In Jakarta, the highest dimension is the orientation to others, whereas achievement, thinking and problemsolving, personal maturity, influence, and directing and controlling are moderate to high. In Balikpapan the highest dimension is an achievement, thinking and problem solving, and orientation to others 
Table 1. Characteristics of Respondents

\begin{tabular}{|c|c|c|c|}
\hline & & \multicolumn{2}{|c|}{ Percentage } \\
\hline & & Jakarta & Balikpapan \\
\hline \multicolumn{2}{|l|}{ Age } & $(n=161)$ & $(n=140)$ \\
\hline 16 & 26 & 42.9 & 12.1 \\
\hline 27 & 37 & 28.0 & 29.3 \\
\hline 38 & $\begin{array}{ll}- & 48\end{array}$ & 15.5 & 37.1 \\
\hline 49 & $\begin{array}{l}-\quad 59\end{array}$ & 11.8 & 20.0 \\
\hline 60 & 72 & 1.9 & 1.4 \\
\hline \multicolumn{2}{|c|}{ Gender } & $(n=161)$ & $(n=139)$ \\
\hline \multicolumn{2}{|c|}{ Male } & 57.1 & 38.1 \\
\hline \multicolumn{2}{|c|}{ Female } & 42.9 & 61.9 \\
\hline \multicolumn{2}{|c|}{ Marital status } & $(n=152)$ & $(n=136)$ \\
\hline \multicolumn{2}{|c|}{ Married } & 57.2 & 86.8 \\
\hline \multicolumn{2}{|c|}{ Not married } & 39.5 & 12.5 \\
\hline \multicolumn{2}{|c|}{ Widow/widower } & 3.3 & .7 \\
\hline \multicolumn{2}{|c|}{ Number of years working as entrepreneur } & $(n=144)$ & $(n=69)$ \\
\hline & $<6$ & 60.4 & 54.5 \\
\hline 6 & $\begin{array}{ll}- & 11\end{array}$ & 21.5 & 23.9 \\
\hline 12 & 17 & 6.9 & 10.3 \\
\hline 18 & $-\quad 22$ & 4.2 & 5.2 \\
\hline 23 & $-\quad 28$ & 3.5 & 2.8 \\
\hline 29 & $\begin{array}{l}-\quad 35 \\
\end{array}$ & 3.5 & 3.3 \\
\hline \multicolumn{2}{|c|}{ Education } & $(n=155)$ & $(n=139)$ \\
\hline \multicolumn{2}{|c|}{ Primary school } & 3.2 & .7 \\
\hline \multicolumn{2}{|c|}{ Junior high school } & 14.2 & 10.8 \\
\hline \multicolumn{2}{|c|}{ Senior High School } & 54.8 & 57.6 \\
\hline \multicolumn{2}{|c|}{ Diploma } & 2.6 & 0.0 \\
\hline \multicolumn{2}{|c|}{ Undergraduate degree } & 23.9 & 29. \\
\hline \multicolumn{2}{|c|}{ Postgraduate degree } & 1.3 & 1.4 \\
\hline \multicolumn{2}{|c|}{ Type of Entrepreneur } & $(n=155)$ & $(n=142)$ \\
\hline \multicolumn{2}{|c|}{ Full-time } & 68.4 & 83.1 \\
\hline \multicolumn{2}{|c|}{ Part-time } & 20.0 & 11.3 \\
\hline \multicolumn{2}{|c|}{ Others } & 11.6 & 5.6 \\
\hline \multicolumn{2}{|c|}{$\begin{array}{l}\text { Monthly revenue } \\
\text { (in millions of rupiah) }\end{array}$} & $(n=156)$ & $(n=131)$ \\
\hline & $<\quad 10$ & 42.3 & 57.3 \\
\hline 10 & 30 & 25.0 & 30.5 \\
\hline 31 & 50 & 10.3 & 8.4 \\
\hline 510 & 100 & 10.3 & 1.5 \\
\hline \multirow[t]{2}{*}{101} & $\begin{array}{l}-\quad 500\end{array}$ & 7.1 & 2.3 \\
\hline & $>\quad 500$ & 5.1 & 0.0 \\
\hline
\end{tabular}


is high, while personal maturity, influence, and directing and controlling is moderate to high.

Table 3 shows that:

- There is a difference in thinking and problem solving between Jakarta and Balikpapan ( $\mathrm{p}<0.05)$.

- There is a difference in directing and controlling between Jakarta and Balikpapan ( $\mathrm{p}<0.1)$.

- There is a difference in orientation to others between Jakarta and Balikpapan ( $p<0.05)$.
- There is no difference in achievement between Jakarta and Balikpapan ( $p>$ $0.1)$.

- There is no difference in personal maturity between Jakarta and Balikpapan ( $\mathrm{p}>0.1)$.

- There was no difference in mean influence between Jakarta and Balikpapan (p> $0.1)$

There is no difference in entrepreneurial competencies between Jakarta and Balikpapan ( $p>0.1)$.

Table 2. Entrepreneurial Competencies

\begin{tabular}{lllll}
\hline Competencies & \multicolumn{2}{l}{ Jakarta $(\mathrm{N}=138)$} & \multicolumn{2}{l}{ Balikpapan (N=117) } \\
\hline Achievement & 5.34 & Moderate to high & 5.40 & High \\
Thinking and problem solving & 5.21 & Moderate to high & 5.44 & High \\
Personal maturity & 5.22 & Moderate to high & 5.28 & Moderate to high \\
Influence & 5.26 & Moderate to high & 5.28 & Moderate to high \\
Directing and Controlling & 5.29 & Moderate to high & 5.10 & Moderate to high \\
Orientation to others & 5.80 & High & 6.12 & High \\
Entrepreneurial Competencies & 5.35 & High & 5.44 & High \\
\hline
\end{tabular}

Table 3. Entrepreneurial Competencies

Independent-Sample t Test

\begin{tabular}{|c|c|c|c|c|c|}
\hline & Area & $\mathrm{N}$ & Mean & Std. Deviation & $\mathrm{t}$-value \\
\hline Achievement & $\begin{array}{l}\text { Jakarta } \\
\text { Balikpapan }\end{array}$ & $\begin{array}{l}159 \\
138\end{array}$ & $\begin{array}{l}5.30 \\
5.33\end{array}$ & $\begin{array}{l}.777 \\
.982\end{array}$ & -0.909 \\
\hline Thinking \& Problem Solving & $\begin{array}{l}\text { Jakarta } \\
\text { Balikpapan }\end{array}$ & $\begin{array}{l}158 \\
136\end{array}$ & $\begin{array}{l}5.18 \\
5.43\end{array}$ & $\begin{array}{c}1.015 \\
.937\end{array}$ & $-2.187^{\mathrm{b}}$ \\
\hline Personal Maturity & $\begin{array}{l}\text { Jakarta } \\
\text { Balikpapan }\end{array}$ & $\begin{array}{l}157 \\
136\end{array}$ & $\begin{array}{l}5.22 \\
5.25\end{array}$ & $\begin{array}{l}.708 \\
.880\end{array}$ & -0.803 \\
\hline Influence & $\begin{array}{l}\text { Jakarta } \\
\text { Balikpapan }\end{array}$ & $\begin{array}{l}158 \\
134\end{array}$ & $\begin{array}{l}5.23 \\
5.28\end{array}$ & $\begin{array}{l}.851 \\
.779\end{array}$ & -0.158 \\
\hline Directing \& Controlling & $\begin{array}{l}\text { Jakarta } \\
\text { Balikpapan }\end{array}$ & $\begin{array}{l}158 \\
135\end{array}$ & $\begin{array}{l}5.27 \\
5.09\end{array}$ & $\begin{array}{l}.961 \\
.948\end{array}$ & $1.653^{\mathrm{c}}$ \\
\hline Orientation to Others & $\begin{array}{l}\text { Jakarta } \\
\text { Balikpapan }\end{array}$ & $\begin{array}{l}157 \\
135\end{array}$ & $\begin{array}{l}5.78 \\
6.09\end{array}$ & $\begin{array}{l}.754 \\
.882\end{array}$ & $-3.216^{\mathrm{a}}$ \\
\hline Entrepreneur Competencies & $\begin{array}{l}\text { Jakarta } \\
\text { Balikpapan }\end{array}$ & $\begin{array}{l}159 \\
138\end{array}$ & $\begin{array}{l}5.32 \\
5.37\end{array}$ & $\begin{array}{l}.787 \\
1.005\end{array}$ & -1.488 \\
\hline
\end{tabular}


Table 4. The Preferred Sub-Sector of Creative Economy

\begin{tabular}{lcc}
\hline \multirow{2}{*}{ Sub-Sector of Creative Economy } & \multicolumn{2}{c}{ Percentage } \\
\hline Applications and Game Development & Jakarta $(\mathbf{n}=\mathbf{1 5 1})$ & Balikpapan $(\mathbf{n}=\mathbf{1 2 4})$ \\
Architecture & 2.0 & 1.6 \\
Product Design & 4.6 & 0.8 \\
Visual Communication Design & 6.6 & 12.1 \\
Interior design & 0.7 & 0.0 \\
Fashion & 3.3 & 1.6 \\
Movie, Animation, and Video & 27.8 & 8.1 \\
Photography & 3.3 & 0.0 \\
Craft & 3.3 & 0.0 \\
Culinary & 1.3 & 16.1 \\
Music & 39.7 & 54.8 \\
Publishing & 2.0 & 0.8 \\
Advertising & 1.3 & 0.0 \\
Performing arts & 1.3 & 1.6 \\
Art & 1.3 & 0.0 \\
Television and Radio & 0.7 & 0.8 \\
Others & 0.7 & 0.8 \\
& 0.0 & 0.8 \\
\hline
\end{tabular}

Table 4 shows that the preferred creative economy sub-sectors for Jakartans are culinary (39.7\%), followed by fashion (27.8\%) and the rest. In Balikpapan, the most popular sub-sector is also culinary (54.8\%), followed by crafts (16.1\%) and the others.

\section{Hypothesis Testing}

\section{Inductive Statistics}

Based on the results displayed in Table 5, it can be concluded that education level has a positive and significant effect on (i) entrepreneurial intention, (ii) entrepreneurial profession attraction, and (iii) entrepreneurial networking support. However, education level does not influence self-reliance.

Additionally, as shown in Table 6; there is a positive and significant correlation between education level and monthly revenue, as well as between entrepreneurial competencies and monthly revenue.

\section{REULTS AND DISCUSSION}

The study finds that entrepreneurial competencies of entrepreneurs in Jakarta and Balikpapan are high. The high dimension of entrepreneurial competencies in Jakarta is the orientation to others dimension, while in Balikpapan it is an achievement, thinking and problem-solving, and orientation to others. Furthermore, there is a positive and significant correlation between entrepreneurial competencies and monthly revenue. This indicates that higher entrepreneurial competencies would lead to higher monthly revenue; hence, entrepreneurs should gradually improve their competencies in order to earn more revenue. They should also consider being trained by professional teachers, who have professional competencies and knowledge-based competencies comprising pedagogical knowledge (Moynihan et al., 2015).

The preferred sub-sectors of creative economy in Jakarta is culinary, followed by fashion and the 
Table 5. Simple Regression Analysis

\begin{tabular}{|c|c|c|c|c|c|c|}
\hline Model $^{\mathbf{a}}$ & $\mathrm{R}$ & $\mathrm{R}^{2}$ & Adj. $\mathrm{R}^{2}$ & F-value & Unstd. $\beta$ & t-value \\
\hline 1. Entrepreneurial Intention (EI) & .111 & .012 & .09 & $3.457^{\mathrm{d}}$ & 34.570 & $12.141^{\mathrm{b}}$ \\
\hline $\mathrm{EI}=\mathrm{EL}+\varepsilon$ & & & & & .411 & $1.859^{\mathrm{d}}$ \\
\hline 2. Professional Attraction (PA) & .137 & .019 & .015 & $5.356^{\mathrm{c}}$ & 19.385 & $13.200^{\mathrm{b}}$ \\
\hline $\mathrm{PA}=\mathrm{EL}+\varepsilon$ & & & & & .264 & $2.314^{c}$ \\
\hline 3.. Networking Support (NS) & .131 & .017 & .013 & $4.623^{c}$ & 15.618 & $18.060^{\mathrm{b}}$ \\
\hline $\mathrm{NS}=\mathrm{EL}+\varepsilon$ & & & & & .145 & $2.150^{c}$ \\
\hline 4. Self-Reliance (SR) & .016 & .000 & -.003 & .075 & 22.431 & $16.622^{\mathrm{b}}$ \\
\hline $\mathrm{SR}=\mathrm{EL}+\varepsilon$ & & & & & -.029 & -.273 \\
\hline
\end{tabular}

Note: a $\mathrm{EI}=$ Entrepreneurial Intention; $\mathrm{PA}=$ Professional Attraction; $\mathrm{EC}=$ Entrepreneurial Capability; $\mathrm{SI}=$ Self Independence; $\mathrm{SR}=$ Self Reliance; $\mathrm{EL}=$ Education Level; ${ }^{\mathrm{b}} \mathrm{p}<0.01 ;{ }^{\mathrm{c}} \mathrm{p}<0.05 ;{ }^{\mathrm{d}} \mathrm{p}<0.1$

Table 6. Correlation Analysis

\begin{tabular}{lcc}
\hline Monthly Revenue & Education Level & Entrepreneurial Competencies \\
\hline Spearman's rho & $.235^{\mathrm{b}}$ & $.135^{\mathrm{a}}$ \\
Sig. (2-tailed) & .000 & .024 \\
$\mathrm{~N}$ & 281 & 279 \\
\hline
\end{tabular}

Note : ${ }^{\mathrm{a}} \mathrm{p}<0.01 ;{ }^{\mathrm{b}} \mathrm{p}<0.05$

remaining sectors. In Balikpapan, the most popular sub-sector is also culinary, followed by a craft and the rest. These preferred sub-sectors correspond with the demand and condition of the respective cities. Culinary is the industry of choice because the food is a basic need. Different cities also have their unique specialties. People are generally proud of their food culture and it is relatively not difficult to market them. Moreover, Jakarta is nation's capital; it is no wonder that it serves as the country's fashion barometer, thus the popularity of fashion industry in Jakarta. While in Balikpapan; the availability of natural resources and distinct culture give rise to the craft industry.

Level of education has a positive and significant effect on (i) entrepreneurial intention, (ii) entrepreneurial profession attraction, and (iii) entrepreneurial networking support. These findings correspond with studies by Krueger
(1993, as referenced in Mushtaq et al., 2011 and Krueger et al., 2000). It can be determined that level of education has an important role in improving entrepreneurial intention and that it can increase the potential for new venture creation. A person's level of education also determines the sustainability of product innovation in a creative economy; proper education and training would ensure a lasting creative economy

Fifty-seven percent of the respondents in Jakarta are male. Plenty of males become entrepreneurs in Jakarta by capitalizing on new business in the culinary and fashion sub-sectors because they can be managed on a part-time basis. Contrariwise, in Balikpapan, the respondents are $61.9 \%$ female. They are homemakers who become entrepreneurs to fulfill household needs. Other than taking care of children, they make the most of their culinary or crafts hobbies by monetizing them. 


\section{MANAGERIAL IMPLICATIONS}

As shown in Table 1, the majority of the respondents are not highly-educated. Based on the findings of this study, the entrepreneurs' education should be upgraded because the level of education not only affects entrepreneurial intention but also increases the potential for new business creations. Most respondents are merely high school graduates. This implies that most of them are necessity entrepreneurs due to the unavailability of alternative jobs. This type of entrepreneurs has a greater risk of failure (Verheul et al., 2010). Furthermore, most of these entrepreneurs have only just begun their businesses; over half of the respondents have only been operating for less than six years. Early stage businesses are vulnerable and more likely to fail (Cowling \& Bygrave. 2003). If these businesspeople are necessity entrepreneurs, then they need to be trained and educated: both hard skill and soft skill competencies. Entrepreneurial skills are required; they increase confidence and focus on providing solutions to work problems. Skill as an entrepreneur is also needed by employees because it can make them more confident and focus on the goal in providing solutions in various problems related to their work tasks (Ikupolati et al., 2017).

Other sub-sectors in the creative industry should also be considered: application and game development; architecture; interior design; visual communication design; product design; movie, animation, and video; photography; music; publishing; advertising; performing arts; art; and television and radio. As Table 4 has shown, the numbers from all the other sub-sectors combined are still lower than culinary. This is certainly an opportunity for every prospective entrepreneur. However, it should be noted that these other sub-sectors require technological acumen. Technology-related education also includes how using technology to transfers money and its accessibility, support costs, and other security factors (Mbogo, 2010). If this advancement is successfully conducted, it can transform necessity entrepreneurs into oppor- tunity entrepreneurs, as well as convert part-time entrepreneurs into full-time.

When it comes to revenue, the majority of the entrepreneurs in this research yield less than 10 million Rupiah every month. Even though this number is greater than the country's minimum wage, it is still the revenue amount and not profit or disposable income. This figure can certainly be increased and one way to do it is through product innovation. The uneven development of the creative economy in Jakarta and Balikpapan necessitate further training, research, and discussion on product innovation, particularly for sub-sectors other than culinary, fashion, and craft. The Indonesian Creative Economy Board should accommodate these advancements in every city.

Enhancement of entrepreneurial competencies through education should be executed in other Indonesian cities as well. As a result, existing local products can be sustained, and product innovations can be strategized. This can give rise to exciting products that are authentic and unique to each culture. Finally, besides product innovation, the entrepreneur should improve their networking behavior, because networking is noted as an important source of sales prospect (Macintosh and Krush, 2017).

In this study, the education level has no effect on self-reliance. This finding needs to be investigated further in next study.

\section{CONCLUSION}

This study finds that level of education has a positive and significant effect on (i) entrepreneurial intention, (ii) entrepreneurial profession attraction, and (iii) entrepreneurial networking support. This is in line with previous studies that affirm the role of level of education in improving entrepreneurial intention and increasing potential new venture creation. (Krueger, 1993 as referenced in Mushtaq et al., 2011; Krueger et al., 2000).Improving the entrepreneurs' level of education should 
be considered because it can positively affect entrepreneurial intention and trigger the potential for new business creation. Furthermore, most entrepreneurs in this research were not highlyeducated.

The findings of this study would suggest the Indonesian Creative Economy Board conduct further research, training, and discussion on product innovation to tackle the uneven development of creative industry in Jakarta and Balikpapan. Product innovation can be the key to increase the revenue of entrepreneurs.

As for other cities in Indonesia, entrepreneurs must progressively improve their competencies in order to keep promoting existing local products, as well as to innovate new products that are authentic and unique to each culture.

REFERENCES

Acho-Chi, C.(1998). Sustainable Self-Development Efforts in Cameroon Grass Fields. Development in Practice, Vol. 8, No. 3, pp. 366-371.

Ajzen, I. (1991). The theory of planned behavior. Organizational behavior and human decision processes. Vol. 50, $179-211$.

Ajzen, I. Fishbein, M. (2005). Theory-based behavior change intervention: comments on hobbis and sutton. Journal of health psychology. Vol. 10, No.1, 27-31.

Alhaj, Baharu Kemat., Yosuf, Mohammed Zain., and Edama, Nita. (2011). Entrepreneurial Intention: An Empirical Study of Community College Students in Malaysia (harat Keusahawanan: Suatu Kajian Empirikal Mengenai Pelajar-Pelajar Kolej Komuniti di Malaysia). Jurnal Personalia Pelajar. Bil. 14 pp. 45-58

Badan Ekonomi Kreatif (Bekraft). (2017). Tonggak Baru ekonomi kretif Indonesia, Retrieved May 08 May 2017 www.bekraf. go.id/profil

Bhola, R., Verheul, I., Thurik, R., and Grilo, I. (2006). Explaining Engagement Levels of Opportunity and Necessity Entrepreneurs. Erasmus University Rotterdam.

Block, J., and Sandner, P. (2009). Necessity and Opportunity Entrepreneurs and their Duration in Self-Employment: Evidence from German Micro Data. Berlin.

Block, J.H., and Wagner, M. (2010). Necessity and Opportunity Entrepreneurs in Germany: Characteristics and Earning Differential. Journal of Schmalenbach Business Review, Vol 62 (April), pp. 154-174.

Callisen, L. (2015). 6 Soft Skills for Entrepreneurs: A Guide to Success.

Cooper, A.C. (1985). The Role of Incubator Organizations in the Founding of Growth-Oriented Firms. Journal of Business Venturing. Vol. 1, No. 1, pp. 75-86.

Cowling, M., and Bygrave, W.D. (2003). Entrepreneurship and Unemployment: Relationship Between Unemployment and Entrepreneurship in 37 Nations Participating in The Global Entrepreneurship Monitor (GEM) 2002. Frontiers of Entrepreneurship Research, pp. 544-555.

Crocker, L., \& Algina, J. (2008). Introduction to classical and modern test theory. Mason, Ohio: Cengage Learning.

Enciety News. (2015). Potensi Industry Kreatif di Surabaya. Retrieved, 09 May 2017 www.enciety.co/potensi-industri-kreatifdi-surabaya/

Gartner, W.B., and Carter, N. (2003). Entrepreneurial Behavior and Firm Organizing Processes. Acs. Z.J., Audretsch., D.B., Handbook of Entrepreneurship Research, Kluwer, Boston, pp. 195-221.

Ikupolati, A.O., Adeyeye, M.M., Oni, E.O., Olatunle, M.A., Obafunmi, M.O., (2017). Entrepreneurs'Managerial Skills as Determinants for Growth of Small and Medium Enterprises (SMEs) in Nigeria. Journal of Small Business and Entrepreneurship Development. Vol 5., No. 1, pp. 1-6.

Kemenperin, Agustus (2015). Industri Kreatif Tumbuh 7\% Per Tahun. Retrived 08 May 2017. http://www.kemenperin.go.id/ artikel/12797/Menperin:-Industri-Kreatif-Tumbuh-7-Per-Tahun 
Kerlinger, F.N. \& Lee, H.B. (2000). Foundations of behavioral research (4th ed.). Australia: Wardsworth Thomson Learning.

Kolveraid, L., and Moen, O. (1997). Entrepreneurship Among Business Graduate: Does a Major in Entrepreneurship Make a Difference?. Journal of European Industrial Training, Vol. 21, No. 4, pp. 154-160.

Krueger, N, Jr.; Reilly, M.; Carsrud, A., (2000). Competing models of entrepreneurial intention. Journal of Business Venturing, V. 15, N.2, p. 177-194

Mbogo, Marion., (2010). The Impact of Mobile Payments on the Success and Growth of Micro-Business: the Case of M-Pesa in Kenya. The Journal of Language, Technology \& Entrepreneurship in Africa, Vol. 2, No. 1 pp. 182-203.

Mohammad, N., Lim, H.E., Yosuf, N., and Soon. (2015). Estimating the Effect of Entrepreneur Education on Graduates' Intention to be Entrepreneurs. Emerald Group Publishing Limited. Vol. 57, No. 89, pp. 874-890.

Mosey, S., and Wright, M. (2007). From Human Capital to Social Capital: a Longitudinal Study of Technology-Based Academic Entrepreneurs. Entrepreneurship Theory and Practice, Vol. 31, pp. 909-935.

Mushtaq, H. Ahmad., Hunjra, Ahmed Imran., Niazi, G.S.K., Rehman, Kashif-Ur., Azam, Rauf I. (2011). Planned Behavior Entrepreneurship and Intention to Create a New Venture Among Young Graduates. Journal Management \& Marketing Challenge for the Knowledge Society, Vol.6, No.3, pp.437-456.

Pro Kaltim, (2016). Jadi Wadah Bagi Pelaku Ekonomi Kreatif. Retrieved May 02, 2016. http://kaltim.prokal.co/read/news/286100jadi-wadah-bagi-pelaku-ekonomi-kreatif.html

Rahman, M.A.(1993). People's Self-Development: Perspectives on Participatory Action Research, Zed Books. London and New Jersey.

Reynolds, P.D., Camp, S.M., Bygrave, W.D., Autio, E., and Hay, M. (2001). Global Entrepreneurship Monitor 2001 Executive Report.

Riyanti, B.P.D., Sandroto, C.W., and Warmiyati, M, T. (2016). Soft Skill Competencies, Hard Skill Competencies, and Intention to Become Entrepreneur of Vocational Graduates. International Research Journal of Business Studies. Vol.9, No. 2, pp. 119-132.

Scarboroug, Norman M., and Cornwall, Jeffrey R. (2016). Essentials of Entrepreneurship and Small Business Management. $8^{\text {th }}$ ed. Boston: Pearson Global Edition.

Shapero, A; Sokol. L. (1982). Social dimension on entrepreneurship. In Kent, C.A, Sexton, \& Vesper, K.H., Eds. Encyclopedia of entrepreneurship. Englewood Cliffs (NJ): Prentice Hall.

Shermon, G. (2004). Competency-Based HRM: A Strategic Resource for Competency Mapping, Assessment and Development Centres. Tata McGraw-Hill

Spencer, L.M.\& Spencer, S.M. (1993). Competence at work. Toronto: John Wiley \& Sons, Inc.

Stephan, Ute., and Uhlaner, Lorraine M. (2010). Performance-Based vs Socially Supportive Culture: A Cross-National Study of Descriptive Norms and Entrepreneurship. Journal of International Business Studies, Vol.41, pp. 1347-1364.

Tian, Yuan., Gao, Changchun., (2011): Management Strategies of Creative Industries Uncertainty, IEEE Journal 978-0-76954464-9/11.

Verheul, I., Thurik, R., Hessels, J., and Zwan, P.Van Der. (2010). Factors Influencing the Entrepreneurial Engagement of Opportunity and Necessity Entrepreneurs. Scientific Analysis of Entrepreneurship and SMEs, (March), 1-26

Wang, Xia0xia., Peng, Ren., (2009): The Creative Industry has come, IEEE Journal 978-1-4244-5268-2/09. 